\title{
Analysis of Tissue-Specific Interferon Regulatory Factor 3 (IRF3) Gene Expression against Viral Infection in Paralichthys olivaceus
}

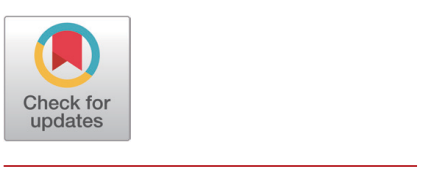

Received: August 29, 2021

Revised: November 6, 2021

Accepted: November 23, 2021

${ }^{+}$Corresponding author

Dain Lee

Fish Genetics and Breeding Research

Center, National Institute of Fisheries

Science, Geoje 53334, Korea.

Tel: +82-55-639-5813

Fax: +82-55-639-5809

E-mail: gene419@korea.kr

Copyright $\odot 2021$ The Korean Society of Developmental Biology.

This is an Open Access article distributed under the terms of the Creative Commons Attribution Non-Commercial License (http://creativecommons.org/licenses/ by-nc/4.0/) which permits unrestricted non-commercial use, distribution, and reproduction in any medium, provided the original work is properly cited.

ORCID

Kyung-Hee Kim

https://orcid.org/0000-0002-8162-3255

Sanghyun Lee

https://orcid.org/0000-0002-5725-666X Jong-Won Park

https://orcid.org/0000-0001-8188-7632 Hyo Sun Jung

https://orcid.org/0000-0001-8690-2408 Julan Kim

https://orcid.org/0000-0003-1964-9486 Hyerim Yang

https://orcid.org/0000-0002-4386-9975 Jeong-Ho Lee

https://orcid.org/0000-0002-2236-3748

Dain Lee

https://orcid.org/0000-0002-5675-8000

Conflict of interests

The authors declare no potential conflict of interest.

\author{
Kyung-Hee Kim, Sanghyun Lee, Jong-Won Park, Hyo Sun Jung, Julan Kim,
} Hyerim Yang, Jeong-Ho Lee, and ${ }^{\dagger}$ Dain Lee

Fish Genetics and Breeding Research Center, National Institute of Fisheries Science, Geoje 53334, Korea

\begin{abstract}
Interferon Regulatory Factor 3 (IRF3) is a member of interferon-regulated transcription factor family and is known to play an important role in the innate immune response against viral infections. In this study, the expression of IRF3 in different tissues, developmental stages, and stocking densities of olive flounder was investigated. The expression of IRF3 was observed to gradually increase in early-stage juvenile fish. The highest expression was observed in later-stage juvenile fish when immune tissues were formed. High IRF3 expression was observed in the muscles and the brain tissues. The expression of IRF3 was observed in fish at different stocking densities after viral hemorrhagic septicemia virus (VHSV) infection. It yielded an interesting expression pattern in the muscles and the brain tissues of fish stocked at low density. These observations can be used as basic data for the study of the expression of immune response-related genes against viruses based on stocking density and immune systems in other fish species.
\end{abstract}

Keywords: Olive flounder Paralichthys olivaceus, Gene expression, Interferon Regulatory Factor 3 (IRF3), Viral hemorrhagic septicemia virus (VHSV), Stocking densities

\section{INTRODUCTION}

Olive flounder (Paralichthys olivaceus) is a saltwater fish belonging to the flounder family. It is a representative species among fish cultured in Korea. Although it is a commercially important fish, productivity has declined due to diseases, increase in breeding density, deterioration of breeding environment, shortage of labor, and increase in aquaculture costs. High-density production to reduce costs has led to an increase in diseases among fish. This factor, in particular, is emerging as a major problem in olive flounder farming (Seo, 2020). In pisciculture, stocking density determines fish growth rate, feed intake rate, aquaculture productivity, and survival rate (Refstie, 1977; Rowland et al., 2006). An increase in stocking density can act as a stress factor for fish and adversely affect their growth (Holm et al., 1990; Björnsson, 1994).

Viral hemorrhagic septicemia virus (VHSV) infection has been reported to cause damage to farmed olive flounders during periods of low water temperatures in winter and spring in Korea. The infection 
Acknowledgements

This work was supported by a grant from the National Institute of Fisheries Science (R2021001).

\section{Authors' contributions}

Conceptualization: Kim KH, Lee D.

Data curation: Lee JH.

Formal analysis: Kim KH, Lee S.

Methodology: Park JW.

Software: Jung HS, Kim J.

Validation: $\mathrm{Kim} \mathrm{KH}$, Yang $\mathrm{H}$.

Investigation: Kim KH, Lee S.

Writing-original draft: Kim KH.

Writing-review \& editing: Kim KH, Lee D.

\section{Ethics approval}

This article has been approved by IACUC by the Animal Experimental Ethics Committee (2020-NIFS-IACUC-17). has also been detected in wild fish (Kim et al., 2003). Infected fish show symptoms such as bleeding of internal organs, skin, and muscles; infection of the eyes, skin, gills, and fins; and abnormal symptoms such as incessant movement (Isshiki et al., 2001; Kim et al., 2009).

Immunity is an important physiological system that detects and effectively defends against external pathogens as organisms evolve and adapt to change in various environments. Immunity is divided into two categories: innate immunity (natural immunity) and adaptive immunity (acquired immunity). In fish, innate immunity is more important because the specificity between antigens and antibodies is low (Magnadóttir, 2006).

Interferons (IFNs) are a type of cytokines that are secreted either by virus-infected cells (type 1 interferons, IFN- $\alpha / \beta$ ) or by engagement of T-cells and NK cells (type 2 interferons, IFN- $\gamma$ ) and are important against some viral infections. There is a type 3 interferon as well that is known to act as a stimulant (Lengyel, 1982; Pestka et al., 1987; Espinosa et al., 2017). The interferon regulatory factor (IRF) family plays an important role in the activation of IFN genes involved in host immune responses. At least 11 members of the IRF family (IRF1 to IRF11) have been identified in vertebrates (Yeow et al., 2000; Huang et al., 2010). Among the IRF family members, IRF3 plays an important role in inducing the expression of the type 1 IFN gene in virus-infected cells and is structurally homologous with IRF7 (Barnes et al., 2002; Huang et al., 2010). In addition, IRF3 is mainly present in the cytoplasm and is ubiquitously expressed in various tissues (Au et al., 1995). Upon viral infection, phosphorylation of specific serine residues in the C-terminal (regulatory) region induces translocation of IRF3 and the NF- $\kappa \mathrm{B}$ protein complex from the cytoplasm to the nucleus. Upon translocation to the nucleus, IRF3 and NF- $\kappa$ B initiate transcription, resulting in the activation of the classical JAK-STAT pathway and interferon-stimulating gene factor (ISGF)3 (Tamura et al., 2008; Wang et al., 2016). Currently, fish IRF3 has been reported in seabass (Lates calcarifer), Grass carp (Ctenopharyngodon idella), rainbow trout (Oncorhynchus Mykiss) and Red sea Bream (Pagrus major), but the results are limited (Holland et al., 2008; Xu et al., 2015; Krishnan et al., 2019; Kim et al., 2020). Therefore, in this study, the expression of IRF3 in olive flounder tissue was analyzed in different developmental stages. The expression of IRF3 in the muscle and brain tissues of fish after VHSV infection at different stocking densities was also analyzed.

\section{MATERIALS AND METHODS}

\section{Breeding and tissue sampling}

The fish used in this experiment was common olive flounder, bred at the Fish Breeding Research Center of the National Institute of Fisheries Science in a 5-ton round tank at a water temperature of $16.8^{\circ} \mathrm{C}$ to $20.4^{\circ} \mathrm{C}$ and a photoperiod of $15 \mathrm{~h}$ of light and $9 \mathrm{~h}$ of darkness. According to the growth of olive flounder, commercial feeds on various size and nutrients were feed. Rotifers were feed as the main food until 3 to 20 days after hatching (DAH), and Artemia was additionally supplied until 13 to 31 days. From the $18^{\text {th }} \mathrm{DAH}$, the compound feed were additionally supplied, and the proportion of the compound feed was gradually increased.

From egg to $50 \mathrm{DAH}$, whole body samples of olive flounder were observed for the expression of each developmental stage. Up to $10 \mathrm{DAH}$ from eggs, sample were sampled so that the amount of sample was $0.1 \mathrm{~g}$, and as growth progressed, 10 sample were crushed and $0.1 \mathrm{~g}$ was used. The samples were placed in TRI-Solution ${ }^{\text {TM }}$ (TS200-001, Bio Science Technology, Daegu, Korea) and stored at $-80^{\circ} \mathrm{C}$ until use. To observe tissue-specific expression, muscles, brain, heart, eyes, fins, skin, gills, stomach, intestines, liver, kidneys, and spleen were extracted from 8-month-old healthy olive flounders (total length approximately $30 \mathrm{~cm}, \mathrm{n}=3$ ) and stored at $-80^{\circ} \mathrm{C}$ in TRI-Solution ${ }^{\mathrm{TM}}$ until the experiment. 


\section{Viral hemorrhagic septicemia virus (VHSV) inoculation}

The purpose of this study was to analyze the expression density of IRF3 in the tissues of healthy 8-month-old olive flounder (total length approximately $30 \mathrm{~cm}, \mathrm{n}=3$ ) after artificial VHSV infection. The fish raised in a 5 -ton tank were transferred to a 3 -ton round tank the day before the experiment and were given no feed. For the experiments, the fish were divided into an experimental group and a control group. The control group was inoculated with $100 \mu \mathrm{L} 1 \times$ PBS (phosphate buffered saline) and the experimental group was inoculated with the VHSV suspension $\left(10^{4.8} \mathrm{TCID}_{50}\right.$ virus/ fish) (Kong et al., 2009). After inoculation, according to the standard manual for olive flounder farming (Kim et al., 2016) and the procedure outlined by Eh (2011), the breeding density was divided into high density (coverage rate 3 ), standard density (coverage rate 1 ), and low density (coverage rate 0.34 ). Samples were taken from the brain and muscle of olive flounders every $0,3,6,9,12$ hours and 1,2,3, 4, 5, 6, 7, 8, 9, 10 days. To minimize the stress of the experimental fish, they were anesthetized with 150 ppm of MS-222 (Sigma-Aldrich, St. Louis, MO, USA). Each tissue was stored at $-80^{\circ} \mathrm{C}$ prior to the experiment (Noh et al., 2017).

\section{3. qRT-PCR}

Total RNA was extracted from $1 \mathrm{~g}$ of sample using the TRI solution protocol. Protein contamination and buffer or phenol contaminations were confirmed spectrophotometrically by measuring A260/280 and A260/230 ratios (Eon ${ }^{\mathrm{TM}}$ Microplate Spectrophotometer, BioTek, Winooski, VT, USA). Total RNA (500 ng) were synthesized using the Transcriptor First Strand cDNA Synthesis Kit (Roche, Mannheim, Germany) for oligo-d(T)18 primers. cDNA (100 ng/ $\mu \mathrm{L}$ ) was subjected to qRT-PCR under the following conditions: initial denaturation at $95^{\circ} \mathrm{C}$ for $20 \mathrm{~s}$, annealing at $58^{\circ} \mathrm{C}$ for $30 \mathrm{~s}$, and elongation at $60^{\circ} \mathrm{C}$ for $30 \mathrm{~s}$. Internal standard control was taken as $18 \mathrm{~S}$ rRNA and quantification was performed using the $2^{-\Delta \Delta \mathrm{Ct}}$ method (Pfaffl, 2001). IRF3 primer (forward: 5'-GAAAGCCAGGTTATCCCAGG-3', reverse; 5'-AGATTGGCTT GGGTTCGATC-3') and 18S rRNA primer (forward: 5'-ATGGCCGTTCTTAGTTGGTG-3', reverse: 5'-CACACGTGATCCAGTCAGT-3') were designed using the Primer3 program after a nucleotide sequence search through the NCBI BLAST database (Rozen \& Skaletsky, 2000).

The results of this study were subjected to one-way analysis of variance followed by Duncan's LSR (least significant range) test using the software package $\mathrm{R}$ version 3.0.1 (Okorie et al., 2013). All data were expressed as mean $\pm \mathrm{SD}(\mathrm{n}=3)$. $p$-values $<0.05$ were considered to indicate statistical significance.

\section{RESULTS}

\section{Interferon regulatory factor 3 (IRF3) expression by developmental stage}

The innate immune response in olive flounder against VHSV was investigated by analyzing the expression of the IRF3 gene during the first 50 days post hatching. mRNA expression through the developmental stages was calculated using $18 \mathrm{~S}$ rRNA primers and relative expression was calculated with respect to expression in egg (its value designated as 1). In addition, quantitative analysis was performed using IRF3-specific primers. The expression of IRF3 in hatchlings from day 1 to day 5 was lower than that in the eggs. The expression gradually increased after day 6 and was highest on day 30 (Fig. 1). After this, it gradually decreased and showed a lower expression than that in the eggs on the day 50 (Fig. 1).

\section{Interferon regulatory factor $\mathbf{3}$ (IRF3) expression by tissue}

To observe the tissue-specific expression of IRF3, healthy olive flounder tissues (muscle, brain, 
heart, eyes, fins, skin, gills, stomach, intestine, liver, kidney, spleen) were used. Tissue-specific mRNA expression was calculated using the $18 \mathrm{~S}$ rRNA primer, and the relative expression with respect to the expression in spleen (its value designated as 1) was investigated. In addition, quantitative analysis was performed using IRF3-specific primers. IRF3 showed the lowest expression in the spleen and the kidneys. The highest expressions were observed in the muscles and the brain (Fig. 2). In addition, high levels of expression of observed in the heart and skin of the eyes (Fig. 2). In the intestine and liver, expression was as low as 4 (Fig. 2).

\section{Interferon regulatory factor 3 (IRF3) expression by density following viral hemorrhagic septicemia virus (VHSV) inoculation}

To study the immune response during viral infection with respect to the stocking density and time lapsed from infection, the mRNA expression of IRF3 was assessed using 18S rRNA primer. The relative expression was investigated with respect to expression at $0 \mathrm{~h}$ post-infection (its value designated as 1). In addition, quantitative analysis was performed using IRF3-specific primers. Experiments were conducted using muscle and brain tissues which, as mentioned in section 3.2, showed high IFR3 expression (Fig. 2).

In the muscle tissue from fish at high stocking density, the mRNA expression gradually increased over time and peaked at $9 \mathrm{~h}$ post-infection. It then decreased gradually and showed the lowest expression on day 3, after which it gradually increased again (Fig. 3A). In the muscle tissue from fish at standard stocking density, expression gradually increased until day 4, after which it decreased (Fig. 3B). In the muscle tissue from fish at low stocking density, the expression was highest at $6 \mathrm{~h}$ post-infection and then gradually decreased (Fig. 3C).

The mRNA expression in brain tissue from fish at high stocking density increased after $0 \mathrm{~h}$ post-infection and showed high expression on day 1 . After a sharp drop on day 3 , it showed a

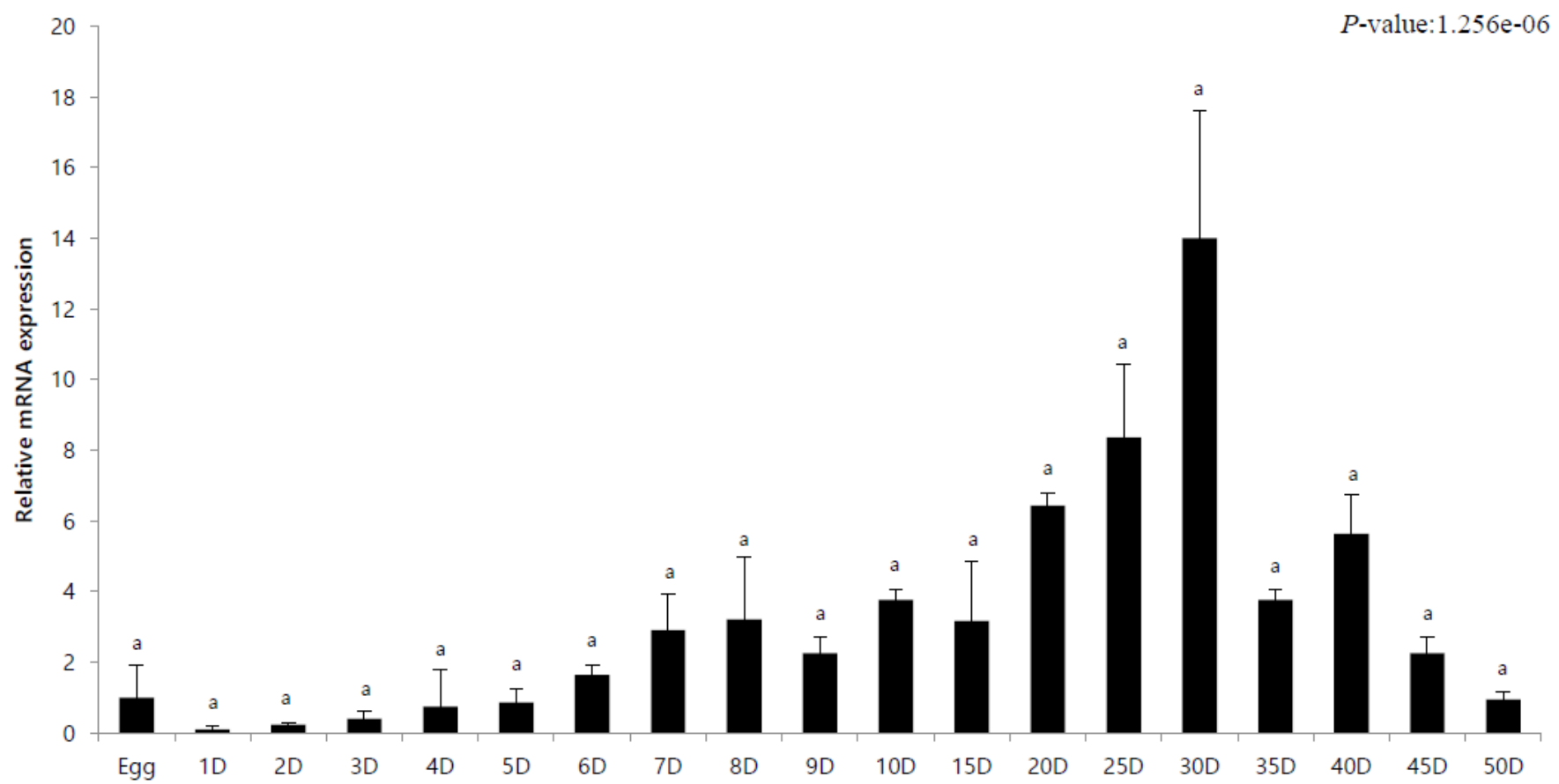

Fig. 1. Expression of IRF3 mRNA in different developmental stage of olive flounder. The mRNA expression of IRF3 was analyzed via qRT-PCR from fertilization though to 50 day old larvae. Each experiment was performed in triplicate and the expression levels of $18 \mathrm{~S}$ rRNA and IRF3 at the egg stage were set as 1 . IRF, interferon regulatory factor. 


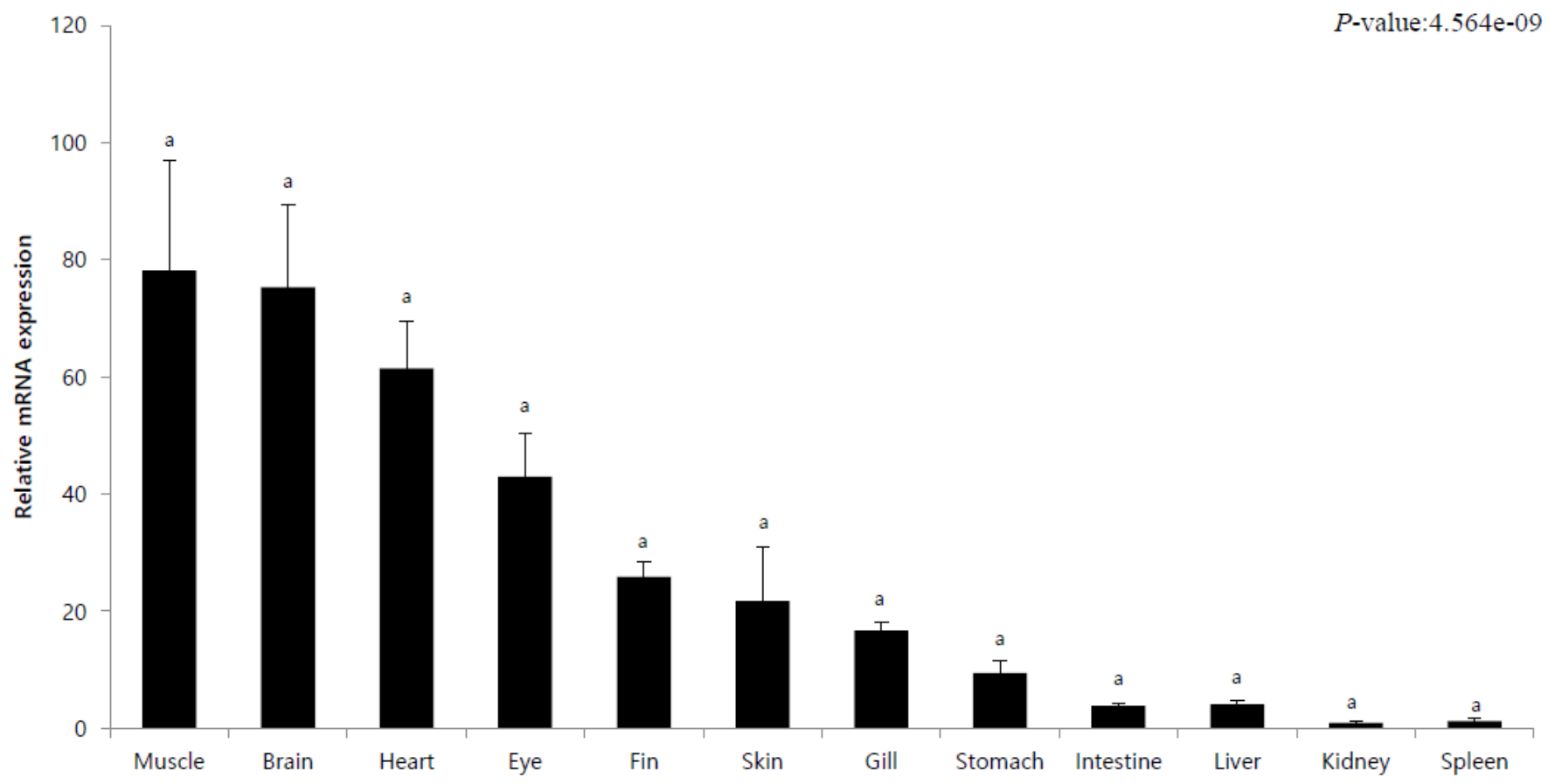

Fig. 2. Expression of IRF3 mRNA in various tissues of olive flounder. IRF3 expression in various tissues was determined via qRT-PCR. Each experiment was performed in triplicate and the expression levels of $18 \mathrm{~S}$ rRNA and IRF3 at the spleen tissue were set as 1. IRF, interferon regulatory factor.

slight upward trend and then showed a high expression on day 10 (Fig. 4A). Brain tissue from fish at standard stocking density showed the highest expression on day 3 and gradually decreased thereafter (Fig. 4B). Expression in brain tissue from fish at low stocking density increased rapidly on day 1 and decreased sharply thereafter (Fig. 4C).

\section{DISCUSSION}

Although flounder is an economically important fish species, there are many problems associated with its farming, such as an increase in mortality, drug use safety, and issues with supply and demand of feed (Kim et al., 2009). VHS, one of the causes of increased mortality, is a contagious disease caused by a viral hemorrhagic sepsis virus. Factors such as fish body size, nutritional status, culture density, water temperature, and water quality affect the onset of VHS. Culture density also affects the overall breeding of farmed fish species. Fish are exposed to many pathogens from the time they are young, produce antibodies and destroy microorganisms as an innate immune response (Magnadóttir, 2006). IRF3 is a member of interferon-regulated transcription factor family and is known to play an important role in the innate immune response to viral infection (Collins et al., 2004). In this study, the innate immune response of olive flounder was quantified using IRF3 gene expression, and the tissue-specific immune response to VHSV and the immune response of VHSV on the basis of aquaculture density were investigated.

According to Han et al. (2007), on day 5, the yolk is completely absorbed, the heart and the liver develop below the esophagus, and morphogenetic differentiation of the digestive tract occurs. Between days 7 and 8 day, the stomach develops. Between days 13 and 14, the digestive tract is fully differentiated and the basic structure of the digestive tract develops (Kim, 2009). On day 
A

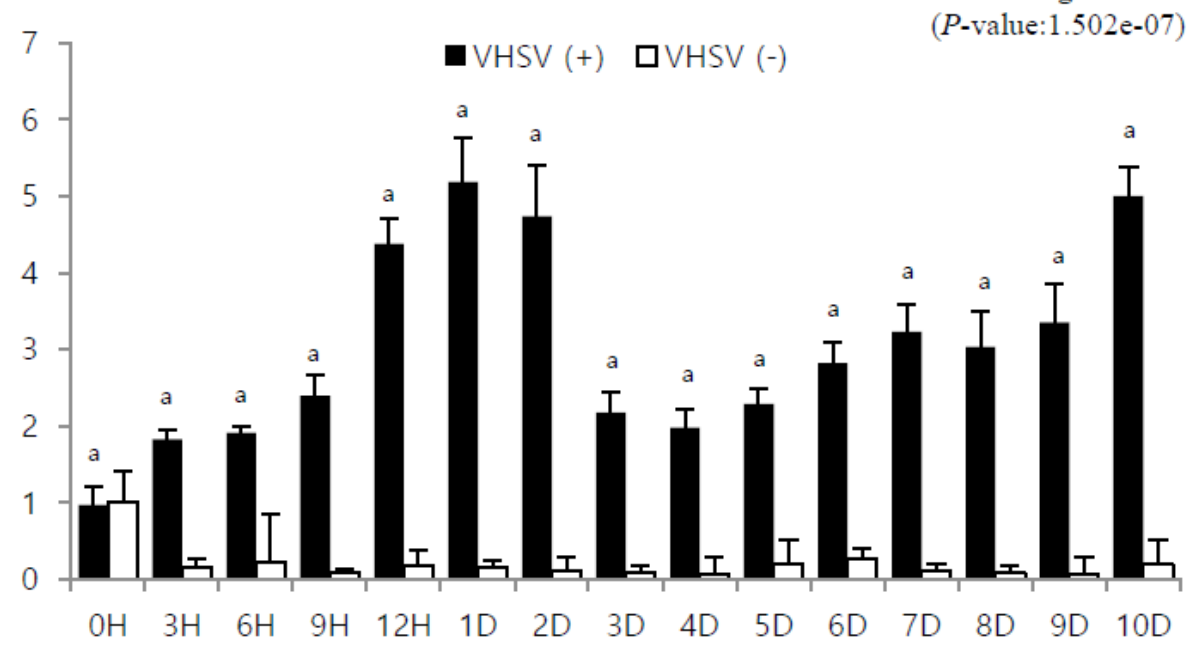

B

Standard

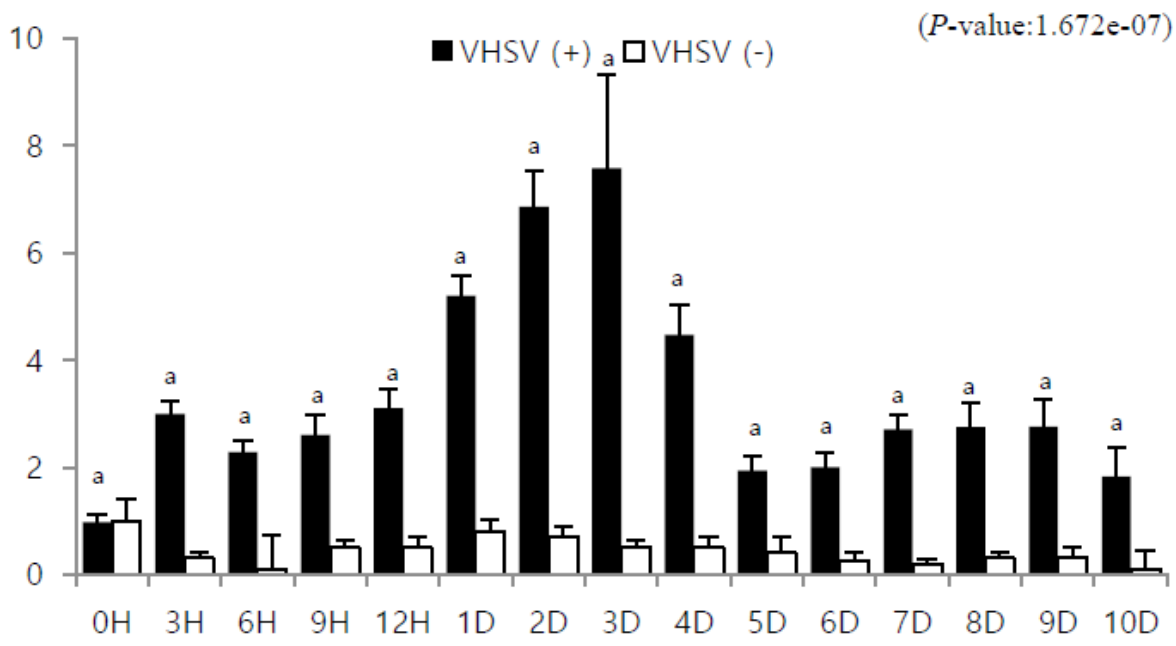

C

Low

$(P$-value: 1.755 e- 07$)$

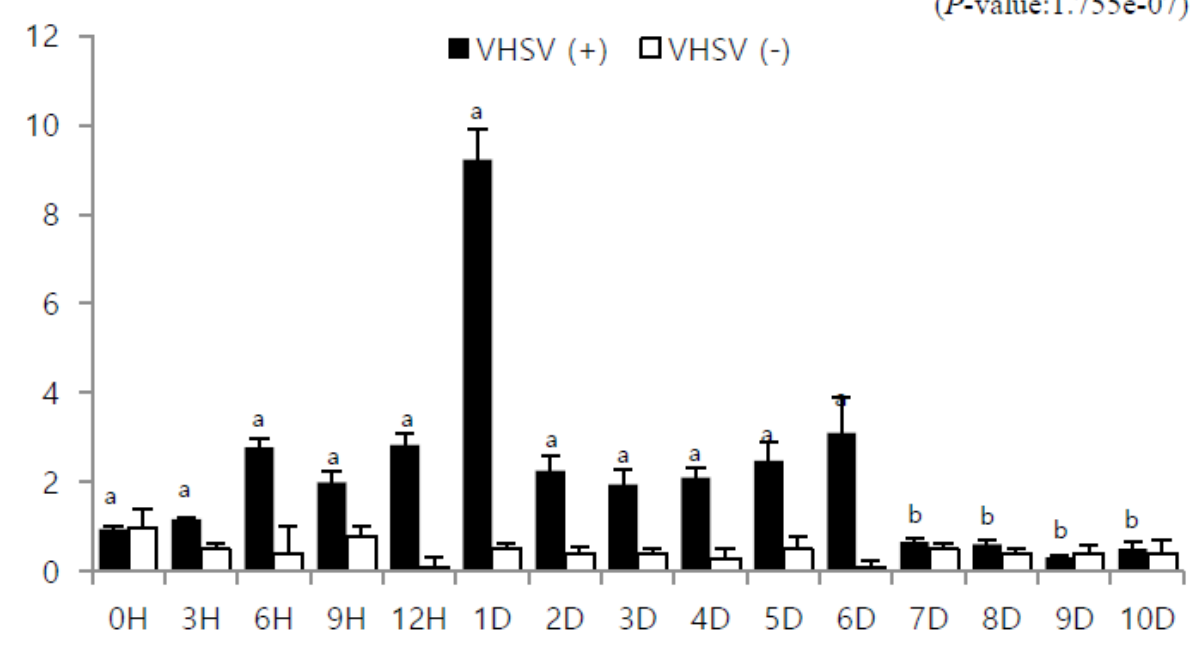

Fig. 3. Relative expression of IRF3 in high (A), standard (B), low (C) stock density at brain tissues of olive flounder within 10 days post-VHSV injection. Each experiment was performed in triplicate and the expression levels of $18 \mathrm{~S}$ rRNA and IRF3 at $0 \mathrm{~h}$ were set as 1 . IRF, interferon regulatory factor. VHSV, viral hemorrhagic septicemia virus. 
A

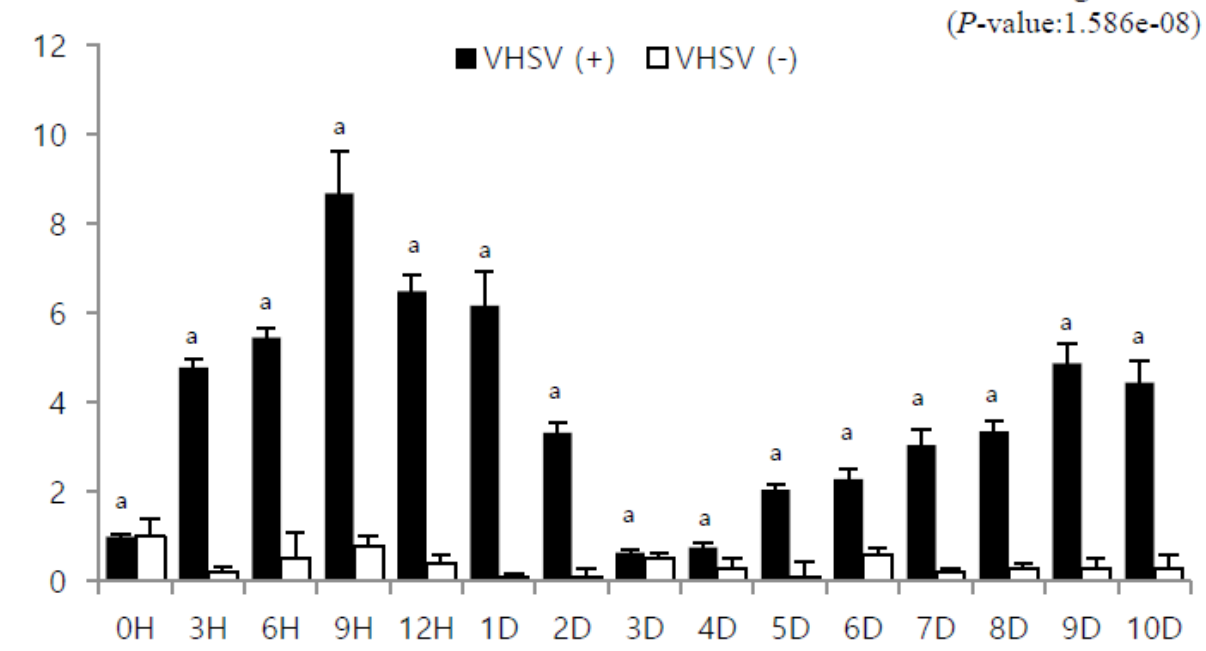

$B$

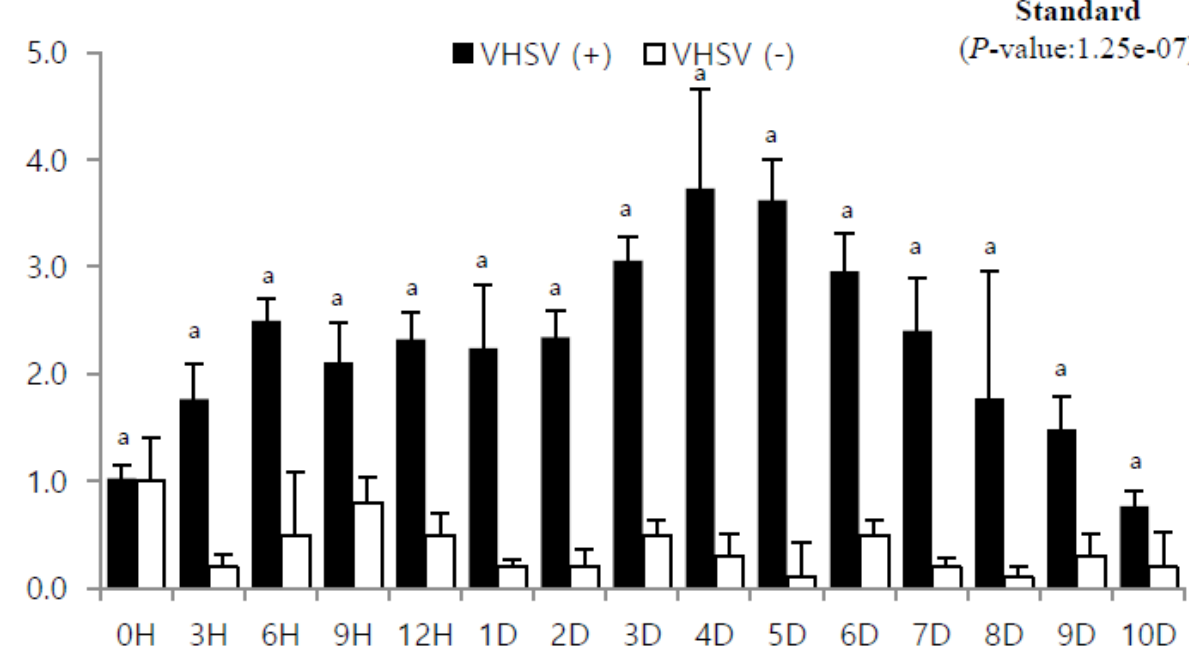

C

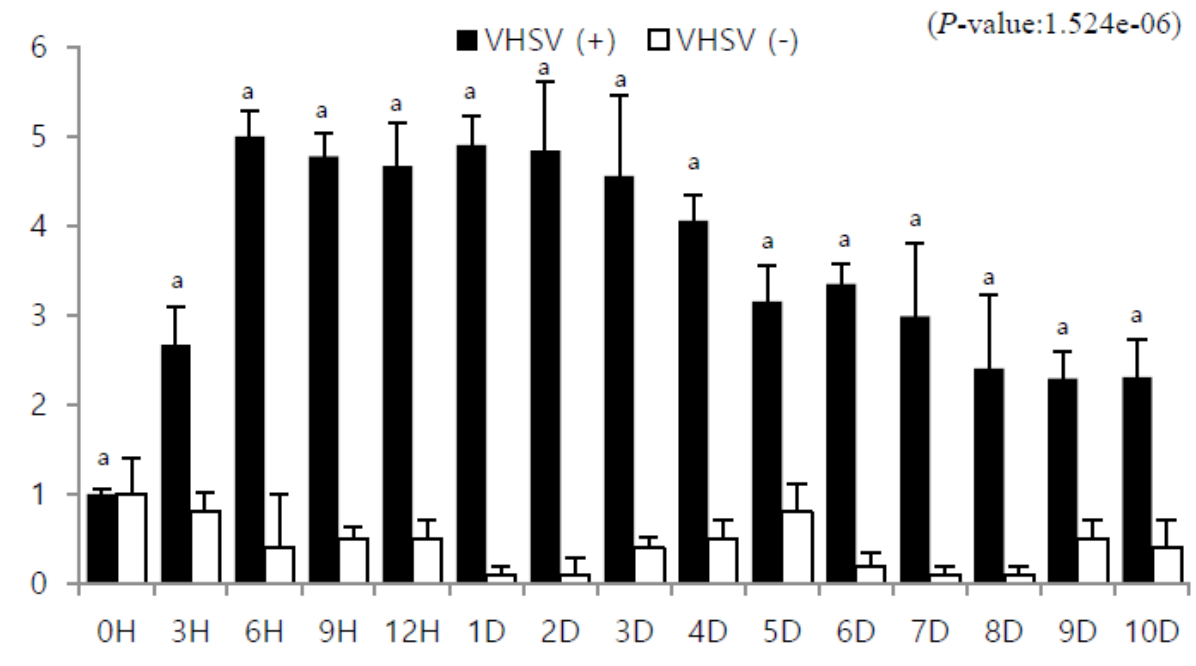

Fig. 4. Relative expression of IRF3 in high (A), standard (B), low (C) stock density at muscle tissues of olive flounder within 10 days post-VHSV injection. Each experiment was performed in triplicate and the expression levels of $18 \mathrm{~S}$ rRNA and IRF3 at $0 \mathrm{~h}$ were set as 1 . IRF, interferon regulatory factor. VHSV, viral hemorrhagic septicemia virus. 
30 , the digestive tract is clearly divided and develops into a structure similar to that of an adult fish. The thymus, kidney, and spleen are the major lymphoid organs in teleosts. The formation of lymphocytes determines when a fish's full immunity is achieved (Zapata et al., 2006). In this study, the expression of IRF3 gradually increased from day 6, showed the highest values on day 30 (the late larval stage), and gradually decreased by day 40 (Fig. 1). The expression of IRF3 gradually increased from the formation of immune tissues, and then decreased after the formation of immune tissues was completed. These results are similar to those of Asian seabass (Krishnan et al., 2019). It was observed that IRF3 has a higher expression in the later juvenile stage, when immune tissue is formed, than in the early juvenile stage and has a significant effect on initial immunity.

IRF3 is a member of the IRF family and is a protein-coding gene containing multiple functional regions, including nuclear export signals, DMA-binding domains, and multiple phenotype phosphorylation sites (Hiscott et al., 1999). Proteins are major transcriptional regulators of type I interferon-dependent immune responses that play an important role in innate immune responses against DNA and RNA viruses (Tanaka \& Chen, 2012). The expression of IRF3 in rainbow trout (Oncorbynchus mykiss) did not show any difference in tissue-wise expression and in Asian seabass (Lates calcarife), the expression was high in the spleen and liver (Holland et al., 2008; Krishnan et al., 2019). In this experiment, the expression was approximately 80 times higher in the muscle and the brain than in the spleen (Fig. 2). Hence, the expression of IRF3 in fish tissues may vary depending on the fish species.

If the stocking density of fish exceeds a certain range, bacteria and parasites multiply rapidly, and mass death and disease may occur. In addition, high-density breeding acts as a stress factor for fish and inhibits growth, while low-density breeding reduces feed intake (Oh et al., 2013; Holm et al., 1990). Adequate aquaculture density lowers the disease incidence and high-density aquaculture increases disease incidence, so aquaculture density can be a criterion for disease incidence (Brock, 1992; Fulks \& Main, 1992). Since the olive flounder is a bottom-dwelling fish, the coverage rate is used as a standard for calculating stocking density, and on a commercial scale, it is better to maintain the coverage ratio of 0.5 to 1 for better growth and survival rates (Kim et al., 2016). High density, standard density, and low density were set based on the standard manual for olive flounder farming based on the appropriate coverage rate $(=1)$. In this experiment, IRF3 expression in olive flounder was observed on the basis of stocking density after VHSV inoculation to understand the variation in immune response. After VHSV inoculation, the expression was generally high in the muscles at low density. The expression gradually increased and then decreased in the muscles at high and standard density (Fig. 4). In addition, the expression gradually increased and then decreased in the brain at high and standard densities; however, at low density, the expression increased rapidly on day 1 , after which it decreased rapidly (Fig. 3). These results conclude that the immune response of olive flounder to VHSV varies with culture density. Further investigation is needed, particularly on the immune response at low density.

\section{REFERENCES}

Au WC, Moore PA, Lowther W, Juang YT, Pitha PM (1995) Identification of a member of the interferon regulatory factor family that binds to the interferon-stimulated response element and activates expression of interferon-induced genes. Proc Natl Acad Sci USA 92:11657-11661.

Barnes B, Lubyova B, Pitha PM (2002) On the role of IRF in host defense. J Interferon Cytokine Res 22:59-71.

Björnsson B (1994) Effects of stocking density on growth rate of halibut (Hippoglossus hippoglossus L.) 
reared in large circular tanks for three years. Aquaculture 123:259-270.

Brock JA (1992) Current diagnostic methods for agents and diseases of farmed marine shrimp. In: Proceeding Asian Interchange Program Workshop on the Diseases of Cultured Penaeid Shrimp, Honolulu, HI, pp 209-231.

Collins SE, Noyce RS, Mossman KL (2004) Innate cellular response to virus particle entry requires IRF3 but not virus replication. J Virol 78:1706-1717.

Eh YY (2011) Productivity of the flounder stocking density on the flounder culture farms. J Fish Bus Adm 42:85-96.

Espinosa V, Dutta O, McElrath C, Du P, Chang YJ, Cicciarelli B, Pitler A, Whitehead I, Obar JJ, Durbin JE, Kotenko SV, Rivera A (2017) Type III interferon is a critical regulator of innate antifungal immunity. Sci Immunol 2:5357.

Han KH, Kim KS, Lee SH (2007) Morphological studies on the digestive tracts of the larvae and juveniles of the flounder, Paralichthys olivaceus. Dev Reprod 11:121-125.

Hiscott J, Pitha P, Genin P, Nguyen H, Heylbroeck C, Mamane Y, Algarte M, Lin R (1999) Triggering the interferon response: The role of IRF-3 transcription factor.J Interferon Cytokine Res 19:1-13.

Holland JW, Bird S, Williamson B, Woudstra C, Mustafa A, Wang T, Zou J, Blaney SC, Collet B, Secombes CJ (2008) Molecular characterization of IRF3 and IRF7 in rainbow trout, Oncorbynchus mykiss: Functional analysis and transcriptional modulation. Mol Immunol 46:269-285.

Holm JC, Refstie T, Bø S (1990) The effect of fish density and feeding regimes on individual growth rate and mortality in rainbow trout (Oncorbynchus mykiss). Aquaculture 89:225-232.

Huang B, Qi ZT, Xu Z, Nie P (2010) Global characterization of interferon regulatory factor (IRF) genes in vertebrates: Glimpse of the diversification in evolution. BMC Immunol 11:22.

Isshiki T, Nishizawa T, Kobayashi T, Nagano T, Miyazaki T (2001) An outbreak of VHSV (viral hemorrhagic septicemia virus) infection in farmed Japanese flounder Paralichthys olivaceus in Japan. Dis Aquat Organ 47:87-99.

Kim KH, Cho DH, Joo MS, Choi KM, Park CI, Kim MC (2020) Molecular characterization and expression analysis of the interferon regulatory factor 3 (IRF3) gene from red sea bream Pagrus major.J Fish Mar Sci Educ 32:1153-1167.

Kim KK, Hwang HK, Kim HC, Kim KW, Cho JW, Jung MH (2016) Olive Flounder Culture Standard Manual. National Institute of Fisheries Science, Busan, Korea.

Kim KS (2009) Study on early development and metamorphosis of Paralichthys olivaceus. Ph.D. Dissertation, Chonnam National University, Gwangju, Korea.

Kim WS, Kim SR, Kim D, Kim JO, Park MA, Kitamura SI, Kim HY, Kim DH, Han HJ, Jung SJ, Oh MJ (2009) An outbreak of VHSV (viral hemorrhagic septicemia virus) infection in farmed olive flounder Paralichthys olivaceus in Korea. Aquaculture 296:165-168.

Krishnan R, Kurcheti PP, Mushtaq Z, Jeena K, Naik VT (2019) Interferon-regulatory factors, IRF3 and IRF7 in Asian seabass, Lates calcarifer: Characterization, ontogeny and transcriptional modulation upon challenge with nervous necrosis virus. Fish Shellfish Immunol 89:468-476.

Kong HJ, Hong GE, Kim WJ, Kim YO, Nam BH, Lee CH, Do JW, Lee JH, Lee SJ, Kim KK (2009) Cloning and characterization of hypusine-containing protein eIF5A from the olive flounder Paralichthys olivaceus. Comp Biochem Physiol B Biochem Mol Biol 153:281-287.

Lengyel P (1982) Biochemistry of interferons and their actions. Annu Rev Biochem 51:251-282. Magnadóttir B (2006) Innate immunity of fish (overview). Fish Shellfish Immunol 20:137-151.

Main KL, Fulks W (1992) Diseases of cultured penaeid shrimp in Asia and the United States. The Oceanic Institute, Honolulu, HI. 
Noh GE, Kim WJ, Kim HC, Park CJ, Park JW (2017) Daily rhythms and effect of short-term starvation on the of health parameters in olive flounder Paralichthys olivaceus. Korean J Fish Aquatic Sci 50:534-540.

Oh DH, Song JW, Kim MG, Lee BJ, Kim KW, Han HS, Lee KJ (2013) Effect of food particle size, stocking density and feeding frequency on the growth performance of juvenile Korean rockfish Sebastes scblegelii. Korean J Fish Aquatic Sci 46:407-412.

Okorie OE, Bae JY, Kim KW, Son MH, Kim JW, Bai SC (2013) Optimum feeding rates in juvenile olive flounder, Paralichthys olivaceus, at the optimum rearing temperature. Aquac Nutr 19:267-277.

Pestka S, Langer JA, Zoon KC, Samuel CE (1987) Interferons and their actions. Annu Rev Biochem 56:727-777.

Pfaffl MW (2001) A new mathematical model for relative quantification in real-time RT-PCR. Nucleic Acids Res 29:e45.

Refstie T (1977) Effect of density on growth and survival of rainbow trout. Aquaculture 11:329334.

Rowland SJ, Mifsud C, Nixon M, Boyd P (2006) Effects of stocking density on the performance of the Australian freshwater silver perch (Bidyanus bidyanus) in cages. Aquaculture 253:301-308.

Rozen S, Skaletsky H. 2000. Primer3 on the WWW for general users and for biologist programmers. In: Misener S, Krawetz SA (eds), Bioinformatics Methods and Protocols: Methods in Molecular biology. Humana Press, Totowa, NJ, pp 365-386.

Seo J (2020) Effects of stocking density on productivity and stress of olive flounder (Paralichthys olivaceus) in recirculation aquaculture system. M.S. Thesis, Pukyong National University, Busan, Korea.

Tamura T, Yanai H, Savitsky D, Taniguchi T (2008) The IRF family transcription factors in immunity and oncogenesis. Annu Rev Immunol 26:535-584.

Tanaka Y, Chen ZJ (2012) STING specifies IRF3 phosphorylation by TBK1 in the cytosolic DNA signaling pathway. Sci Signal 5:ra20.

Wang Z, Ji J, Peng D, Ma F, Cheng G, Qin FXF (2016) Complex regulation pattern of IRF3 activation revealed by a novel dimerization reporter system.J Immunol 196:4322-4330.

Xu X, Lai Q, Gu M, Liu D, Hou Q, Liu X, Mi Y, Sun Z, Wang H, Lin G, Hu C (2015) Fish IRF3 up-regulates the transcriptional level of IRF1, IRF2, IRF3 and IRF7 in CIK cells. Fish Shellfish Immunol 47:978-985.

Yeow WS, Au WC, Juang YT, Fields CD, Dent CL, Gewert DR, Pitha PM (2000) Reconstitution of virus-mediated expression of interferon $\alpha$ genes in human fibroblast cells by ectopic interferon regulatory factor-7.J Biol Chem 275:6313-6320.

Zapata A, Diez B, Cejalvo T, Gutiérrez-de Frías C, Cortés A (2006) Ontogeny of the immune system of fish. Fish Shellfish Immunol 20:126-136. 